\title{
Microstructure and Mechanical Properties of the AISi13Mg1CuNi Alloy With Ecological Modifier
}

Assoc. Prof. Tomasz Lipiński Dr.Sc.

University of Warmia and Mazury in Olsztyn, The Faculty of Technical Sciences Department of Materials and Machines

Technology, St: Oczapowskiego 11, 10-957 Olsztyn, Poland. tomasz.lipinski@uwm.edu.pl

A homogenous modifier obtained by the rapid solidification at a cooling rate equal to $\mathrm{v}=200 \mathrm{~K} / \mathrm{s}$ was applied to the modification of the AISi13Mg1CuNi alloy. The different modifiers were obtained by means of the Al-Si alloys containing 0,7 and 12 at. \% Si, respectively. The components Al, Al-7Si, Al-12Si were put into crucible containing the liquid AlSi13Mg1CuNi alloy. Both, effect of cooling rate applied to obtain modifier and weight in weight modifier concentration in the melt on microstructure, tensile strength and hardness of AISi13Mg1CuNi alloy are determined. A structural, physical and mechanical properties resulting from the AlSi13Mg1CuNi alloy treatment by modifiers are studied in details.

Key words: Al-Si alloy, silumin, mechanical properties, ecological modification, homogenous modificator

\section{References}

[1] АХНАЗАРОВА С.Л., В.В. КАФАРОВ (1978). Оптимализация эксперимента в химии и химической технологии. Издательство Высшая школа. Москва.

[2] BORKOWSKI S., M. ZIĘBACZ-NIESMACZNY, T. LIPIŃSKI AND M. MERMER (1996). Ř́zení jakosti litiny s využitím metody dmýchání př́sad. Slévárenstvi 4, pp. 281-283.

[3] KOPYCIŃSKI D. AND E. GUZIK. (2008). Effective inoculation of low-sulphur cast iron. Archives of Foundry Engineering vol.8, $\mathrm{nr}$ 4, pp. 77-80.

[4] LIPIŃSKI T. (2003). Hardness AK7 alloy after treatment by microalloy mixtures. Technical Sciences No 6, pp.167174.

[5] LIPIŃSKI T. (2005). Improwment of mechanical properties of Al-Si cast alloy. Pobočka České Slévárenské Společnosti při Katedře Slévárenství, FMMI, VŠE - TU Ostrava. Sborník mezinárodni konference Výzkum a Vývoj ve Slévárenství. VŠB-Technická Univerzita Ostrava, pp. 104-107.

[6] LIPIŃSKI T. (2008). Improvement of mechanical properties of AlSi7Mg alloy with fast cooling homogenous modifier Archives of Foundry Engineering vol.8, nr 1, pp. 85-88.

[7] LIPIŃSKI T. (2010). The structure and mechanical properties of Al-7\%SiMg alloy treated with a homogeneous modifier. Solid State Phenomena Vol. 163, pp 183-186.

[8] MICHNA S., I. LUKAC, V. OCENASEK, R. KORENY, J. DRAPALA H. SCHNEIDE a kol. (2005). Encyklopedie Hliniku. Adin,s.r.o., Presov. 